\title{
Historical note: early years of the 1946 British birth cohort study
}

\section{David Blane}

Imperial College London and ESRC International Centre for Life Course Studies in Society and Health.

\author{
d.blane@imperial.ac.uk
}

The article by Michael Wadsworth in the previous issue of this journal (Wadsworth 2010) prompted thoughts about the importance to life course studies of social history. Wadsworth demonstrated this relevance in his pioneering volume The Imprint of Time (Wadsworth 1991). The present text adds a little further information about the social history of the parents of the 1946 cohort and the 1946 cohort's early years. The social history of a birth cohort's parents is a relevant, if somewhat neglected topic, because it shapes the ideas and values which surround the cohort during its early years of dependency. At the time the 1946 cohort was born, over 70 per cent of the male population was employed in manual occupations, with them and their families assigned to one of the manual social classes. The present historical note mentions some possibly relevant features of their experience.

The recruits to the 1946 British birth cohort study mostly were conceived during July 1945 , the month in which Attlee's post-war Labour Government was elected, and gestated by mothers who had endured nearly six full years of war. The experience of women during the 1939-1945 war shaped the mental and physical health which the mothers brought to conception and gestation, while the ideas with which they raised their young children were coloured also by their socialisation in the pre-war world and the reality of post-war austerity. Each of these phases presents a complex picture of benefits and hardships, with a woman's likelihood of experiencing one rather than the other being linked to their social class. Working class mothers were most likely to have suffered hardship at one or more points: pre-war; wartime; post-war austerity.

The older mothers of the 1946 cohort had fathers and brothers killed in World War I or crippled by gas or amputation; and often carried rickets from the failure to add vitamin $D$ to the wartime whale oil margarine or heart valve defects from childhood rheumatic fever. All knew of neighbours and kin invalided or dead by respiratory tuberculosis. The ubiquitous out-door toilet ensured that bedrooms smelt of urine from the chamber pot under the bed; and insect infestation in the fabric of poor terraced housing encouraged their inhabitants to sleep in the street during the summer months. High unemployment due to the mass closure of heavy industry in the north and west of Britain was, in time, counter-balanced by new light industry in the midlands and south-east. Routes out of the working class were offered by the merchant marine, police, nursing and teaching, where women had to resign on marriage. Suburban homes, bought on mortgage, were strip-built along Metroland, allowing more space in the centre of cities. The cinema, cigarettes and lipstick brought a new glamour to life. Cycling and motor-bikes allowed escape from locality; truck driving along the developing national road network was an adventure of navigation and machine repair; and crystal wireless brought the international into everyday life. The cruelties of the Poor Law (means testing; break-up of families on entry to Work House; the able-bodied forced to tramp every day to the next Work House) ensured a terror of relying on welfare (Spring Rice 1939; Greenwood 1939; Stevenson 1984).

Total war brought a best-ever approximation to full employment, producing women's wages which enabled the purchase of rationed food, supplemented by the distribution of clothing coupons which could be sold to the more affluent via their domestic servants and, for those with means, food off ration from restaurants and the black market. Growing vegetables and keeping chickens became popular. Family life was disrupted by the evacuation of children, conscription of men, bombardment by aeroplane or prototype intercontinental ballistic missile and, particularly during the Atlantic war and after D-Day, the dreaded killed in action telegram. This drab and rather miserable 
life of long hours of work, sleeping in air-raid shelters, bland diet and constant anxiety, which lasted as long as a person's adolescence, was enlivened by the modest pleasures of friends, wireless, cinema and music (Calder 1969; Kennedy 1989; Titmuss 1950).

The end of the European war in May 1945 and the Pacific war in August 1945 brought transient celebration, an ominous demonstration at Nagasaki and Hiroshima of the threat that would dog the adolescence and early adulthood of the 1946 birth cohort and the onset of a period of post-war austerity which in some respects was harsher than the war-time years.

Within this general context, three aspects of life are examined next in a little more detail.

\section{Health services}

The quality of the antenatal care available to the mothers of the 1946 birth cohort, indeed whether they received any at all, was influenced by their ability to pay, which often was lacking, and by the skewed distribution of General Practitioners: prewar there had been proportionately seven times as many general practitioners in affluent South Kensington as in industrial South Shields (Titmuss $1950,71)$. The condition of the hospitals in which they gave birth varied from terrible to not particularly good. A series of surveys by the Ministry of Health in 1938, in preparation for the war, found in the words of Richard Titmuss: large old-fashioned wards, out-of-date kitchens, poor and insufficient equipment, inadequate or non-existing laboratories, ugly prison-like buildings and old, dilapidated structures (Titmuss 1950, 69-70). Typical was South Wales, where only three out of 141 hospitals had staffed and equipped laboratories (Titmuss 1950, 70). Specialist doctors were thin on the ground; for example, there were no paediatricians in the eastern counties of England (Titmuss 1950, 71). War-time planning and investment improved the situation by tackling the regional maldistribution of medical specialists, via the Emergency Medical Service, and by up-grading the medical infrastructure with some 80,000 new hospital beds in hutted wards, nearly 1,000 new operating theatres, equipped with as many new surgical instruments as had been ordered in the previous 30 years and X-ray machines and pathology laboratories (Titmuss 1950, 83). The post-war National Health Service (NHS) built on these improvements, but came too late for the birth and infancy of the 1946 cohort, who were well into adulthood before the war-time hutted wards joined as relics of the past, the TB sanatoriums and 2,000-plus bedded psychiatric asylums of their youth (DHSS 1975).

In a remarkably prescient discussion of why, despite many hardships, civilian death rates did not deteriorate during the war, and the stillbirth and infant mortality rates in particular improved during 1942-46, Richard Titmuss identified a number of important contextual and life course influences (Titmuss 1950, 537-538). The most relevant aspects of the wartime experience were: full employment, which mitigated food restriction by poverty; policy initiatives such as food rationing, national milk scheme, raising the extraction rate of flour, British restaurants and works canteens; thirdly, good fortune in avoiding epidemic influenza and respiratory disease and typhoid caused by, respectively, crowded bomb shelters and bombdamaged sewers. The life course argument rested on reasoning: It was not an accident that with each succeeding year of the Second World War there was an increasing number of mothers bearing children who had themselves been born and bred in more favourable circumstances than previous generations of mothers (Titmuss 1950, 535), which Titmuss attributed to the secular trends of rising living standards and decline in the number of children per family. Many of these influences continued into the early life of the 1946 British birth cohort.

\section{Social conditions}

By 1945 over two-thirds of national resources were directly employed on work for the Government (Robinson 1951), orchestrated by a civil service which had quadrupled in size and recruited almost every economist and statistician in the land (Hopkins 1951). From their point of view, the nutritional initiatives lauded by Titmuss were meshed with Anglo-American supply agreements, agricultural price controls and war agricultural executive committees, with input from a Scientific Food Policy Committee which advised a Basal Diet consisting largely of wholemeal bread and potatoes, giving a daily adult ration of 2,800 calories (Nash 1951).

Two months before the members of the 1946 birth cohort were conceived, food rations were cut. In ounces per person per week, sugar (8oz), sweets 
(4oz), cheese (2oz), butter (2oz) and margarine $(4 \mathrm{oz})$ remained unchanged from wartime levels, as did milk (2.5 pints per person per week) and eggs (1 per person per fortnight), but cooking fat was cut by $50 \%$ (to 1 oz per person per week), bacon by $25 \%$ (to $30 z$ per person per week) and points from 24 to 20 per person per month: 4 points $=$ tin baked beans; 17 points $=$ small tin spam (Waller 2004).

Disappointment that diet worsened with the end of war, rather than improving as expected, sudden intolerance of endless queuing, coal shortages during the harsh winter of 1945-46 and widespread bomb damage to houses, combined to ensure that the 1946 cohort were not delivered into easy conditions. The wartime diary of George Beardmore, a BBC staff member, for 3 June 1945 (around conception of 1946 cohort) records: Food is scarce. Most days I go to the British Restaurant for a mid-day meal. I suffer from stretches of lassitude, mostly in the evening when I usually like to go gardening. I put it down to deficiency in this or that protein or vitamin (Beardmore 1986, 195); and for 3 March 1946 (around birth of 1946 cohort): Two wretched families have moved into a requisitioned mansion nearby... Have twice visited... A scene of squalor and misery rare even in these days. A bus conductor, two women and three schoolchildren, driven desperate for somewhere to live, camp out in a large dilapidated room without light, water and (yesterday at least) fuel for a fire. Sullen, dirty faces swollen with colds (Beardmore 1986, 200).

The austerity of the 1946 cohort's early childhood years derived from the poor state of Britain's finances at the end of the war: large foreign debts; visible exports at $40 \%$ of pre-war levels; invisible exports, like shipping, much reduced; civilian industry run down after six years of war; the end of Lend-Lease (Calder 1969). Slowly families re-assembled, with demobilisation and the return of evacuated children, often meeting again as virtual strangers. Food rationing and the housing shortage continued into the next decade, with the urban working class particularly affected, and some nutritional categories, cheese, eggs and vegetables, remaining at sub-wartime levels throughout 194649 (Ministry of Food 1951). Many of those returning home were physically or mentally scarred; rehabilitation, prosthetics and plastic surgery for the former were rudimentary, while the latter was largely undiagnosed and untreated. There was a feeling among those returning that the war had stolen their youth (Grafton 1981) and some women among those who had remained were reluctant to resign their paid employment (Sheridan 1990). Improvements came slowly: by the time of the next decennial census, in 1951 when the 1946 cohort were entering primary school, nearly half of all households lacked sole use of a fixed bath; one-infive lacked piped water; $85 \%$ left school at the minimum leaving age of 15 years; and 2.6\% attended university (Carr-Saunders, Caradog Jones and Moser 1958).

\section{Men}

What of the fathers of the members of the 1946 British birth cohort study? Three things stand out from contemporary social studies as potentially relevant (Zweig 1949; Rowntree and Lavers 1951; Zweig 1952). In the main, fathers were little involved in the raising of their children; men's social attitudes were little changed by the wartime experience of we're all in this together; the marked upward social mobility of the post-war generation, from working class to middle class, was not fuelled by their fathers' ambition.

Most men of working age were in paid employment in manual occupations, working 50 hours or more per week, depending on overtime, spread over five-and-a-half or six days; plus travelling from home to work, and back, by bicycle, bus or train for anything up to 90 minutes each way (Zweig 1949; Zweig 1952). Pleasures mostly were outside the home, perhaps driven by residential crowding: tobacco and alcohol in the pub; gambling on greyhounds, horses and football pools; cinema, dancing and sometimes theatre; low grade deviancy, street betting, petty dishonesty, sexual promiscuity (Rowntree and Lavers 1951), with comparatively little involvement in the practice of religion, politics, civic society or adult education; reading and wireless were the main home pleasures (Zweig 1952). These weekly routines, combined with little or no paid holiday, predisposed to limited contact between fathers and offspring.

Ferdynand Zweig, professor of political economy at Cracow University, given wartime refuge by University of Oxford, was puzzled by the attitudes of British workers towards their employers and the wider social order, which he regarded as conservative and constrained by long institutional memories of past grievances and abuses - cotton spinners referring to their strike of 50 years earlier, 
for example. Zweig seems to have assumed that social attitudes would change as a result of full employment, nationalisation and the welfare state, and expected that the post-war economic crisis would produce the same national unity as the war had done. He was a good enough social scientist to recognise that what he found contradicted his assumptions, but failed to consider explanations other than 'long institutional memories'. Some historians (Calder 1969; Grafton 1981; Sheridan 1990) have documented the class-based nature of World War II in Britain; to the extent they are correct, the continuities in social reality from the 1930s through the 1939-45 war to the late 1940s mean that Zweig's findings do not require explanation - the continuity in social attitudes was based on continuity in the social structure.

Zweig (1952) found a working class with fine internal stratification by prestige and hourly rates of pay:

- Casual labourers, often in poor physical or mental health.

- Light labourers, often reserved for the elderly.

- General labourers, loading, unloading, mixing cement.

- Heavy labourers or navvies.

- Craftmen's labourers, a semi-skilled mate.

- Handymen, performing small routine jobs under a craftsman's supervision.

- Semi-skilled men, who increased proportionately with mechanisation.

- Craftsmen, who had completed an apprenticeship of five to seven years.

- Leading hands - craftsmen who set standards in a workshop.

- Sub-foremen and foremen, midway between junior management and workers.

Workers' ambitions for themselves and their children were confined to movement between these strata, with little consideration of movement into the middle class of white-collar workers, via educational qualifications (Zweig 1949; Zweig 1952).

\section{Ruminations}

The preceding brief comments raise three interesting questions. The members of the 1946 British birth cohort were conceived, gestated, delivered and raised through infancy and early childhood in pretty tough conditions, yet they belong to a generation whose current life expectancy at middle age is increasing too fast for the pension system to cope. Has recent research interest in early life been over-done? Perhaps more attention should be given to continuities over the life course such as, for the 1946 cohort, never conscripted to fight a war, working life spent in a full employment economy, steady improvement in the material conditions of life? Second, recent interest in waning rates of social mobility have concentrated on supply side phenomena like parental aspirations and educational opportunity, yet the 1946 cohort achieved historically high rates of social mobility despite low parental aspirations and low rates of further and higher education. Perhaps more weight should be given to demand side phenomena such as, in the case of the 1946 cohort, the creation and expansion of the nationalised industries and the welfare state? Finally, the above summary which gives due weight to working class experience, is somewhat at odds with the structure of the 1946 cohort, with its onein-four sampling of the working class. Given selective attrition out of this 1:4 sample by social deviance and disadvantage, how representative are the surviving cohort members who were born into the working class; how adequate are the standard weighting procedures; what are the size and direction of the biases which may have resulted?

\section{References}

Beardmore G. (1986) Civilians at war: journals 1938-1946. Oxford University Press, Oxford.

Calder A. (1969) The People's War: Britain 1939-45. Jonathan Cape, London.

Carr-Saunders A, Caradog Jones D and Moser C. (1958) A Survey of Social Conditions in England and Wales. Clarendon Press, Oxford.

Department of Health and Social Security. (1975) Health and Personal Social Service Statistics for England.

Table 4.1. HMSO, London.

Grafton P. (1981) You, You \& You: people out of step with World War II. Section 24. Pluto, London.

Greenwood W. (1939) How the Other Man Lives. Labour Book Service, London. 


\section{NOTES, COMMENT AND DEBATE}

Hopkins R. (1951) Introductory note. In: D Chester, ed. Lessons of the British War Economy. Pp 1-4. University Press, Cambridge.

Kennedy L. (1989) War Papers. Fontana, London.

Ministry of Food. (1951) National Food Survey: The Urban Working Class Household Diet 1940-1949. HMSO, London.

Nash E. (1951) Wartime control of food and agricultural prices. In: D Chester, ed. Lessons of the British War Economy. Pp 200-238. Cambridge, University Press, Cambridge.

Robinson E. (1951) The overall allocation of resources. In: D Chester ed. Lessons of the British War Economy. Pp 34-57. University Press, Cambridge.

Rowntree S and Lavers G. (1951) English Life and Leisure. Longmans, London.

Sheridan D, ed. (1990) Wartime Women: a Mass-Observation anthology of the experiences of women at war. Chapter 20. Heinemann, London.

Spring Rice M. (1939) Working Class Wives. Penguin Books, London.

Stevenson J. (1984) British Society 1914-45. Allen Lane, London.

Titmuss R. (1950) Problems of Social Policy: History of the Second World War; United Kingdom Civil Series. Longmans Green, London.

Wadsworth MEJ. (2010) The origins and innovatory nature of the 1946 British national birth cohort study. Longitudinal and Life Course Studies 1, 121-136.

Wadsworth MEJ. (1991) The Imprint of Time, Clarendon Press, Oxford.

Zweig F. (1949) Labour Life and Poverty. Gollancz, London.

Zweig F. (1952) The British Worker. Penguin, London. 